\title{
Treatment of Parkinson's disease using human stem cells
}

\author{
Charlotte Palmer", Raquel Coronel ${ }^{*}$ and Isabel Liste* \\ Neural Regeneration Unit. Functional Unit of Chronic Disease Research. Carlos III Health Institute (ISCIII), Majadahonda, Madrid, Spain
}

\begin{abstract}
The progressive loss of dopamine neurons (DAn) in the substantia nigra is the main characteristic of Parkinson's disease (PD), the second most common neurodegenerative disorder causing several motor symptoms. Current treatment options for PD are available to help relieve primary motor symptoms, but their longterm effectiveness is limited and they do not stop neuronal degeneration. For this reason, alternative treatment options are being sought in the form of cell replacement therapies (CRT). Several open label clinical trials involving the intrastriatal transplantation of human fetal ventral mesencephalic tissue (hfVM) has provided proof of concept that CRT could be beneficial for some patients, providing relief of motor symptoms. However, the lack of availability of tissue and ethical issues limit the clinical use on a large scale of this strategy, therefore being sought alternative cell sources, based on the use of human stem cells.
\end{abstract}

In this review we provide an overview of the different types of human stem cells currently available, mainly multipotent and pluripotent stem cells, their advantages and disadvantages from an experimental and clinical point of view, and how they are being developed clinically for PD treatment.

\section{Introduction}

Parkinson's disease (PD) is a progressive neurodegenerative disorder resulting from the loss of dopamine-producing neurons (DAn) in the substantia nigra pars compacta (SNpc) [1-3]. In addition, $\mathrm{PD}$ patients present with the deposition of $\alpha$-synuclein-positive protein aggregates called Lewy bodies and neuro-inflammation in various brain regions, further contributing to the progression of the disease [4-6]. The loss of SNpc DAn triggers the recognizable primary motor symptoms, including tremor, rigidity and bradykinesia [7]. However, the pathology of PD is now known to extend beyond the nigrostriatal dopaminergic pathway itself, leading to a number of secondary motor and non-motor symptoms that can be just as debilitating [8]. Although the precise etiology of PD is still unknown, a variety of pathogenic mechanisms have been proposed. These may include the loss of trophic support, excessive release of oxygen free radicals, a dysfunctional mechanism of protein degradation, abnormal kinase activity and impairment of mitochondrial function [4].

A variety of treatment options are available to help manage motor symptoms. These include medications in the form of the dopamine precursor levodopa (L-dopa), dopaminergic agonists, or inhibitors of dopamine breakdown (catechol-O-methyl transferase and monoamine oxidase inhibitors) or surgical procedures such as deep brain stimulation (DBS) $[8,9]$. With time, however, these treatments cease to be effective, and some of them are known to develop unpleasant side effects, such as dyskinesias. Most importantly, these treatments are not a cure. They are not reparative of basal ganglia circuitry, nor capable of stopping the disease from progressing $[8,10,11]$.

For this reason, alternative treatment options are currently being investigated, among them is particularly interesting the cell replacement therapy (CRT). Here we summarize general approaches for experimental and clinical applications of stem cell therapy, discussing the common issues, different strategies and how they are being developed as a possible treatment option for PD.

\section{Transplants of human fetal ventral mesencephalic tissue}

Transplants of human fetal ventral mesencephalic (hfVM) tissue have been developed in the clinic for more than 30 years for PD treatment [12]. These grafts contain immature midbrain DAn and their progenitors, which are generally transplanted into the striatum (the target region of nigral DAn) where they are expected to release and replenish dopamine levels.

Preclinical studies performed in the 1970s and 1980s in animal models of PD demonstrated that DAn obtained from the fetal midbrain were able to survive transplantation in animal models of PD, integrate into host tissue, release dopamine and improve motor function. With this background, several groups were able to conduct open label clinical trials in $\mathrm{PD}$ patients, providing proof of principle that hfVM grafts can be an efficient and safe treatment option for PD. However, two double-blind, placebo-controlled clinical trials failed to meet their primary endpoint $[13,14]$, and the overall results obtained from all trials were fairly inconsistent, both between and within trials. For this reason, several limiting challenges are still being faced in turning fetal VM grafts into a comparative treatment option for PD. The first challenge is to avoid further inconsistencies in the results, which can be achieved by establishing better standardization procedures and improved trial design [14-16]. The second challenge is the probability of the host developing an immune reaction, since all the transplants

Correspondence to: Isabel Liste, Neural Regeneration Unit, Functional Unit of Chronic Disease Research. Carlos III Health Institute (ISCIII), 28220 Majadahonda, Madrid, Spain, Tel: +34 918223292; Fax: +34 918223269; E-mail: iliste@isciii.es

\section{"Equal contribution}

Key words: stem cells, cell therapy, dopamine neurons, Parkinson's disease, neurodegeneration

Received: September 28, 2016; Accepted: October 31, 2016; Published: November 02, 2016 
are allogenic [17-20]. The third, and arguably the biggest, is the ethical concerns with using fetal tissue, and the difficulty in obtaining enough tissue for a successful transplant.

To help overcome these challenges, the European consortium TRANSEURO (www.transeuro.org.uk), a multicenter clinical trial that is currently working to analyze the feasibility and effectiveness of transplantation of human fetal cell suspensions in PD patients, in hopes of providing more consistent results for a better understanding of the potential therapeutic benefit [21-23] (Table 1).

Interestingly, in a recently published study it has shown that grafts of hfVM can survive for at least 24 years inside the denervated putamen of a Parkinson's patient, with no signs of inflammation [24]. The patient had clinically improved during the first decade post-implantation, although eventually this improvement began decreasing, indicating that the transplant was no longer functional. The histopathological analysis showed that approximately $12 \%$ of the neurons of the graft were positive for $a$-synuclein, reflecting the transfer of the host brain pathology to the implanted neurons [24].

\section{Human stem cell-based therapies for PD treatment}

Due to the above limitations of using fetal tissue, important research efforts are currently underway to find alternative types of cells for transplantation in PD. Several sources have been explored, and the most promising so far have been stem cells. Stem cells are undifferentiated cells that have the ability to differentiate to more specialized cell types. Because of these properties, they are currently considered the best option for developing a uniform source of DAn to be used for cell replacement therapy.

In recent years it has made enormous progress in this field, which has made it possible to obtain human dopaminergic precursors from different types of stem cells such as: human Embryonic Stem Cells (hESCs) [25-28], human induced Pluripotent Stem Cells (hiPSCs) [29-32], human Neural Stem Cells (hNSCs) from fetal [33,34] or adult brains [35], and even human Mesenchymal Stem Cells (hMSCs) [36] by transdifferentiation (Figure 1). Basically, stem cells can be classified as pluripotent, when they retain the ability to differentiate to all cell types, or multipotent, when they are more specialized and give rise to a specific cell line [37-39].

In general, in the research field it is assumed that in order for the stem cells to become a clinically competitive treatment option, these cells need to be equivalent to those of hfVM tissue. And after grafting they must be able to survive, re-innervate the striatum and integrate into the neural circuitry of the host. They also have to significantly improve motor symptoms, cause no side effects and meet a number of safety requirements, such as eliminating the risk of tumor formation, immune response and the development of dyskinesias [40,41].

\section{Human multipotent stem cells}

\section{Human neural stem cells}

Human Neural Stem Cells (hNSCs) are multipotent stem cells with the ability to generate all neural cells of the CNS. They can be obtained from fetal, neonatal and adult brains or from the directed differentiation of pluripotent stem cells. In theory, the human VM neural precursors are considered the ideal candidates for cell therapies in PD, but as mentioned above, their use is very limited. Furthermore, they present poor growth potential, unstable phenotypes (especially upon repeat passage), and survive poorly in the brain after grafting $[34,42,43]$.

Different techniques have been developed to optimize the expansion of these cells, including the formation of neurospheres in the presence of growth factors such as basic Fibroblast Growth Factor (bFGF) and Epidermal Growth Factor (EGF) [44,45] or the transduction with immortalizing genes such as v-Myc, c-Myc or TERT $[34,46]$. Furthermore, in a different approach an efficient method involving the addition of Wnt5a showed a 6-fold increase in the amount of midbrain DAn obtained, as compared to the starting VM preparation [47].

However, currently there are several clinical trials involving the use of hNSCs of different origin. The company Celavie Bioscences, LLC, is conducting a clinical trial consisting in the intraputaminal injection in PD patients of undifferentiated human fetal stem cells (OK99 cell line) obtained from a fetal brain tissue and growth in a bioreactor. This is a phase 1, open-label and safety study which aims to analyze the potential efficacy of this type of grafting for PD treatment (Table 1).

Table 1. Human stem cells used currently in clinical trials (www.clinicaltrials.gov) for treatment of Parkinson's disease.

\begin{tabular}{|c|c|c|c|c|}
\hline Stem cell type & Transplant type & Method and target & Status and identifier & Sponsor \\
\hline \multirow[t]{3}{*}{$\begin{array}{l}\text { hNSCs from fetal ventral } \\
\text { mesencephalic tissue }\end{array}$} & Allogenic & $\begin{array}{l}\text { Intracerebral } \\
\text { implantation }\end{array}$ & $\begin{array}{l}\text { Phase } 1 \\
\text { NCT01898390 }\end{array}$ & $\begin{array}{l}\text { TRANSEURO Project } \\
\text { University of Cambridge }\end{array}$ \\
\hline & Allogenic & Not provided & $\begin{array}{l}\text { Phase } 1 / 2 \\
\text { NCT01860794 }\end{array}$ & Bundang CHA Hospital \\
\hline & Allogenic & $\begin{array}{l}\text { Intracerebral } \\
\text { implantation }\end{array}$ & $\begin{array}{l}\text { Phase } 1 / 2 \\
\text { NCT02538315 }\end{array}$ & University of Saskatchewan \\
\hline hNSCs from fetal brain & Allogenic & Intraputaminal implantation & $\begin{array}{l}\text { Phase } 1 \\
\text { NCT02780895 }\end{array}$ & Celavie Bioscences LLC \\
\hline hNSCs from adult cerebral cortex & Autologous & Intracerebral implantation to the left putamen & $\begin{array}{l}\text { Phase } 0 \\
\text { NCT01329926 }\end{array}$ & $\begin{array}{l}\text { NeuroGeneration } \\
{[35]}\end{array}$ \\
\hline ISC-hpNSCs & Allogenic & $\begin{array}{l}\text { Intracerebral implantation to striatum and } \\
\text { substantia nigra }\end{array}$ & $\begin{array}{l}\text { Phase } 1 \\
\text { NCT02452723 }\end{array}$ & $\begin{array}{l}\text { Cyto Therapeutics } \\
\text { Pty Limited }\end{array}$ \\
\hline \multirow[t]{2}{*}{ hMSCs from bone marrow } & Allogenic & Intravenous administration & $\begin{array}{l}\text { Phase } 1 / 2 \\
\text { NCT02611167 }\end{array}$ & The University of Texas Health Science Center \\
\hline & Autologous & Intravenous administration & $\begin{array}{l}\text { Phase } 1 / 2 \\
\text { NCT01446614 }\end{array}$ & $\begin{array}{l}\text { Guangzhou General Hospital of Guangzhou } \\
\text { Military Command }\end{array}$ \\
\hline \multirow[t]{2}{*}{ hMSCs from adipose tissue } & Autologous & $\begin{array}{l}\text { Delivered to vertebral artery and intravenous } \\
\text { administration }\end{array}$ & $\begin{array}{l}\text { Phase } 1 / 2 \\
\text { NCT01453803 }\end{array}$ & Ageless Regenerative Institute \\
\hline & Autologous & Not provided & $\begin{array}{l}\text { Recruiting } \\
\text { NCT02184546 }\end{array}$ & StemGenex \\
\hline
\end{tabular}




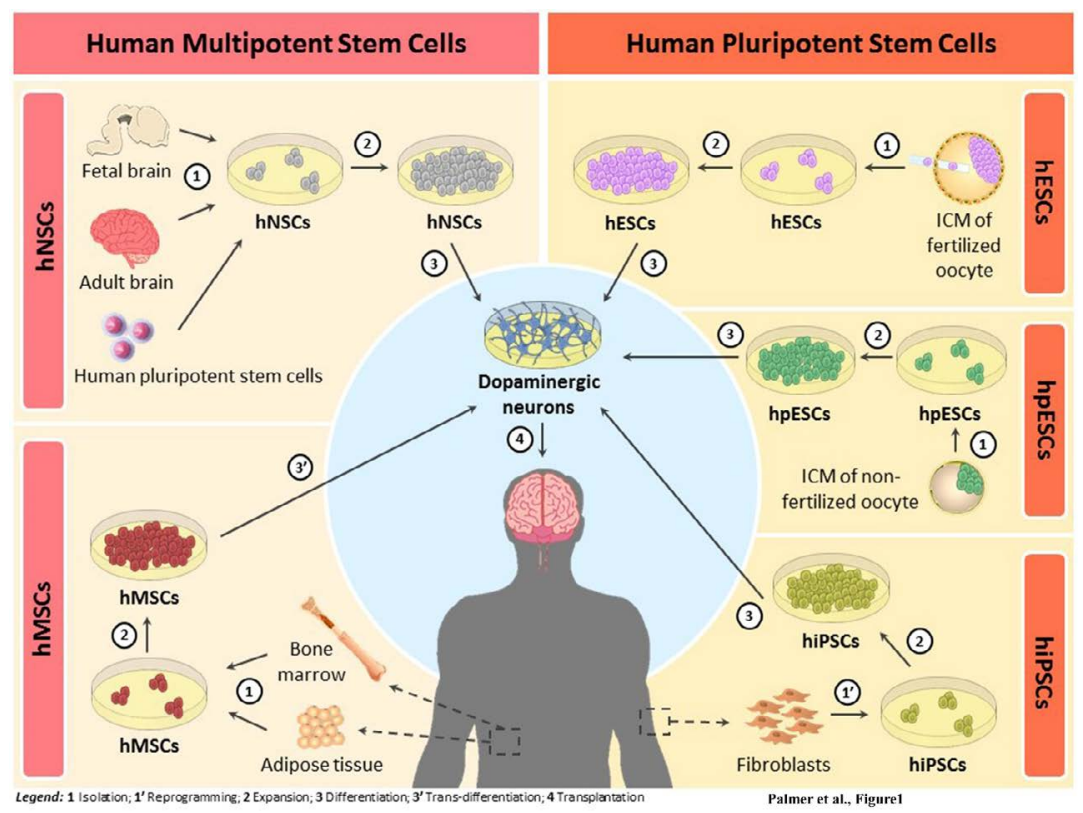

Figure 1. Schematic illustration of the different types of human stem cells currently available for their potential application in cell replacement therapy (CRT) for Parkinson's disease (PD) They can be classified as human Neural Stem Cells (hNSCs), human Mesenchymal Stem Cells (hMSCs), human Embryonic Stem Cells (hESCs), human parthenogenetic Embryonic Stem Cells (hpESCs) and human induced Pluripotent Stem Cells (hiPSCs). hNSCs are multipotent cells isolated from fetal and adult brains or from differentiation of human pluripotent stem cells (1) that can be expanded in large number (2) and then differentiated into dopaminergic neurons (3) for transplantation (4). hMSCs are also multipotent cells derived from adult bone marrow or adipose tissue (1) that after its expansion (2) and trans-differentiation into dopaminergic neurons (3'), they can be transplanted in PD patients (4). hESCs and hpESCs are pluripotent cells isolated from the inner cellular mass (ICM) of fertilized oocytes and the ICM of non-fertilized oocytes, respectively (1), that can be expanded in large number (2) and then differentiated into dopaminergic neurons (3) for transplantation (4). hiPSCs are reprogrammed adult somatic cells (eg. fibroblasts) (1'), with many similarities to the hESCs, that after its expansion (2) and differentiation into dopaminergic neurons (3), they can be transplanted in PD patients (4).

In a different approach, the company NeuroGeneration Inc have obtained hNSCs from biopsies from the own patient, which after culturing and expansion were differentiated to neurons (approximately $14 \%$ of these neurons were DAn) and transplanted into PD patients. These patients showed some clinical improvements, but clinical trials are ongoing to determine the safety and efficacy of this strategy (Table 1 and Figure 1) [35].

\section{Human mesenchymal stem cells}

Human Mesenchymal Stem Cells (hMSCs) are non-hematopoietic and multipotent self-renewing cells arising easily from adult bone marrow [48], adipose tissue [49], umbilical cord blood [50], dental pulp [51], placenta and brain [52,53]. In the last few years, these cells have emerged as a promising approach to regenerative medicine due to their great proliferative potential and widespread availability in the body [54]. hMSCs are stromal cells that exhibit a multi-lineage differentiation potential of mesodermal origin (generally into adipocytes, osteocytes and chondrocytes) [55-57]. Besides regulating differentiation subclasses, the potential for trans-differentiation to a neural lineage (ectodermal origin), and even to a DAn phenotype, have been demonstrated [39,53,55,58-61]. However, this remains somewhat controversial, as inconsistent results are unable to confirm the ability of these cells to correctly integrate into the host-neural circuitry to form synaptic connections $[36,57,62]$.

An alternative approach is utilizing the ability of hMSCs to secrete protective neurotrophic factors, growth factors and cytokines (including VEGF, HGF, IGF-1, BDNF, $\beta$-NGF, TGF- $\beta$, FGF2 and GDNF) that are known to promote protection, repair and exhibit immunomodulatory effects, by contributing to immunosuppression in the brain and inhibiting the release of pro-inflammatory cytokines
(TNF- $\alpha$, IL-1 $\beta$ and INF- $\gamma$ ) detected in brains of PD patient [63-65]. Additionally, hMSCs is attractive clinically because, if isolated from an autologous source, they would circumvent the need for immunological regimes and eliminate any ethical concerns [54,66-68]. Further more if infused systemically, they have shown the ability to migrate to sites of injury in animals, suggesting migratory capacity towards damaged areas where they can then promote repair processes [54].

Despite this evidence, their use in clinical trials has been limited due to the heterogeneous nature of populations isolated from different tissues [69]. However, hMSCs from bone marrow or adipose tissue are currently being used to investigate the efficacy of autologous and allogenic treatments in PD patients with the idea of taking advantage of their immune-modulatory and trophic properties, and antiinflammatory effects [70] (Table 1, Table 2, Figure 1).

The University of Texas Health Science Center is conducting a clinical trial consisting in the intravenous administration of allogenic bone marrow-derived hMSCs into PD patients. Apart from of safety, feasibility and efficacy studies, they are assessing some changes in immunologic response but so far it has not disclosed any data or result of this strategy. In other different trial, the Ageless Regenerative Institute has obtained adipose tissue-derived hMSCs from the abdomen of PD patients to study safety and efficacy of this type of transplant for PD treatment. This is a phase $1 / 2$, but study results have not posted still (Table 1 and Figure 1).

\section{Human pluripotent stem cells}

\section{Human embryonic stem cells}

Human Embryonic Stem Cells (hESCs) were isolated for the first time in 1998, from the inner cell mass of the blastocyst stage embryos 


\begin{tabular}{|c|c|c|c|}
\hline Stem cell type & Transplant type & Advantages & Disadvantages \\
\hline \multirow[t]{4}{*}{ hNSCs } & \multirow[t]{3}{*}{ Allogenic } & \multirow[t]{2}{*}{ Differentiation into specific neural linage (including DAn) } & Limited source tissue \\
\hline & & & Ethical concerns \\
\hline & & Lower risk of tumor formation and immunological rejections than $\mathrm{hESCs}$ & Histocompatibility concerns \\
\hline & & & Risk of graft-induced dyskinesias \\
\hline \multirow[t]{6}{*}{ hMSCs } & \multirow[t]{6}{*}{ Autologous and allogenic } & Widespread availability by the body and easily accessible & Inconsistent results on integration in host-neural circuitry \\
\hline & & Potential for trans-differentiation into neural linage (including DAn) & Modest clinical improvement in humans \\
\hline & & $\begin{array}{l}\text { Immunosuppression in the brain and inhibition of pro-inflammatory } \\
\text { cytokines }\end{array}$ & \\
\hline & & Migratory capacity towards damaged areas & \\
\hline & & No histocompatibility concerns (in autologous transplant) & \\
\hline & & No ethical concerns & \\
\hline \multirow[t]{6}{*}{ hESCs } & \multirow[t]{6}{*}{ Allogenic } & Differentiation into specialized cells from all three germ layers & Risk of tumor formation \\
\hline & & Potential for production limitless of DAn & Ethical concerns \\
\hline & & $\begin{array}{l}\text { Survive transplantation and some degree of functional recovery in animal } \\
\text { models }\end{array}$ & Histocompatibility concerns \\
\hline & & & Phenotypic instability \\
\hline & & & Safety concerns \\
\hline & & & Legislation of most countries limit their use in clinical trials \\
\hline \multirow[t]{3}{*}{ hpESCs } & \multirow[t]{3}{*}{ Allogenic } & Differentiation into specialized cells from all three germ layers & Risk of tumor formation \\
\hline & & Potential for production limitless of DAn & Ethical concerns \\
\hline & & & Lack of paternal contribution \\
\hline \multirow[t]{7}{*}{ hiPSCs } & \multirow[t]{7}{*}{ Autologous and allogenic } & Differentiation into specialized cells from all three germ layers & Risk of tumor formation \\
\hline & & Potential for production limitless of DAn & Epigenetic memory \\
\hline & & No histocompatibility concerns (in autologous transplant) & Mutations occurring during reprogramming \\
\hline & & No ethical concerns & Phenotypic instability \\
\hline & & & Safety concerns \\
\hline & & & Low hiPSCs yield \\
\hline & & & Elevated production cost \\
\hline
\end{tabular}

of fertilized oocytes [71], and at that time they were considered the optimal source for cell replacement therapies due to their pluripotent state without the need for reprogramming (Table 2).

In order to make hESCs applicable for clinical use in treating PD, they must meet a number of strict requirements concerning efficient differentiation to functional neurons with the correct DAn phenotype. As such, numerous different protocols have been developed, the most efficient to date are those involving the formation of embryoid bodies, dual SMAD inhibition and the use of Shh and Wnt signaling agonists that efficiently convert floor plate precursors into DA neurons $[25,27,72-74]$.

However, several challenges persist, such as high ethical concerns, the risk of tumor formation, phenotypic instability and the risk of host-graft rejection due to the difficulty of HLA typing $[21,26,75,76]$. Furthermore, it is crucial to eliminate risk of contamination with animal products by following GLP/GMP (Good Laboratory and Manufacture Procedures) to optimize their use for clinical application (Figure 1).

Despite the high expectations generated, there are still no clinical trails using ESCS to treat PD. However clinical trails are planned and at least one of them is awaiting approval by the FDA and it is expected can begin at the end of 2017 [77].

\section{Human parthenogenetic embryonic stem cells}

Another type of pluripotent stem cells are those derived by parthenogenesis named human parthenogenetic Embryonic Stem Cells (hpESCs). Parthenogenesis in mammalian oocytes can be induced by electrical on chemical stimuli that mimic sperm penetration. Thus hpESCs are pluripotent cells derived from unfertilized oocytes that show typical hESCs morphology, express appropriate pluripotency markers, possess high alkaline phosphatase levels, high telomerase activity, generate embryoid bodies in culture and form teratomas after injection to immunodeficient animals $[78,79]$.

However, the lack of paternal contribution could make their clinical use problematic, as normal cell cycle progression and proper differentiation could be affected (Table 2). At the end of 2015, the very first clinical trial with pluripotent stem cells for treating PD was approved, and involves the use of hpESCs [78]. This is a phase 1 study to evaluate the safety and therapeutic benefit of transplantation of hNSCs derived from differentiation of hpESCs and injected into the striatum and substantia nigra of PD patients. The trial will be conducted by the company Cyto Therapeutics Pty Limited at the Royal Melbourne Hospital. (Table 1 and Figure 1).

\section{Human induced pluripotent stem cells}

Human induced Pluripotent Stem Cells (hiPSCs) are obtained from adult somatic cells by reprogramming and they share many similarities with those of hESCs, including cell morphology, expression of pluripotent markers, epigenetic changes, potential to differentiate into cells of the three germ layers in vitro and in vivo (by teratoma formation) and the ability to generate viable chimeras $[2,80]$.

hiPSCs were described for the first time in 2006 by Takahashi and Yamanaka; this discover was a remarkable breakthrough in the stem cell research- and regenerative medicine fields. They achieved this goal by the introduction of four main transcription factors Oct3/4, Sox2, Klf4 and c-Myc to re-induce a state of pluripotency [81]. iPS cell technology offers exciting possibilities for biomedical research in PD. These cells can be used as in vitro cellular models of the disease and be a source of autologous cells that would not raise ethical concerns. For PD in particular, human DA precursors have been efficiently derived 
from hiPSCs following similar protocols as those used to differentiate hESCs [25,29-32].

Despite their promise, several challenges continue to limit the use of hiPSCs to large-scale clinical level. It is expected that these cells generate similar problems as hESCs, as well as problems of epigenetic memory of autologous tissue, genomic instability, problems with the reprogramming process itself, especially when integrating viral vectors are used and the risk of teratoma formation [82].

The expectations placed on hiPSCs remain huge. Several clinical trials involving their use to treat PD are already planned and are currently awaiting government approval. One is expected to begin in Japan soon, led by the group of Jun Takahashi [83-85] (Figure 1). One of the great advantages of iPSCs in relation to ESCs is the ability to generate patient-specific cells, which, in theory, would avoid the use of immunosupressants. However, so far, the process itself is too expensive to be done on a large scale [86].

\section{Conclusions and future perspectives}

The current treatment options available for most neurological disorders, including PD, only provide temporary symptomatic relief but do not prevent the disease from progressing. Therefore, the development of cell-replacement therapies could provide substantial benefits for PD patients. The rationale of CRT in PD is to replace the lost DAn in PD with immature and healthy DAn to restore neuronal circuits and dopamine levels.

Previous open label clinical trials in PD patients with hfVM cell suspensions have shown that these grafts can be an efficient and safe treatment option for at least some PD patients. However, ethical and tissue availability problems, limit their widespread clinical use.

In theory, the human VM neural precursors are considered the ideal candidates for cell therapies in PD, but their use is very limited. Furthermore, they present poor growth potential, unstable phenotypes (especially upon repeated passage), and survive poorly in the brain after grafting; therefore must seek new cell sources (Table 2).

The enormous progress made in recent years in the stem cell research field has made it possible to obtain human dopaminergic precursors from different types of stem cells including hMSCS by transdifferentiation and specially from human pluripotent stem cells (hESCs and hiPSCs) (Figure 1). hMSCs are clinically attractive because they can be isolated from the own patient, so they would circumvent the need for immunological regimes and eliminate any ethical concerns. The potential for transdifferentiation into DAn phenotype, have been shown in different studies [60-62]. However, this process remains somewhat controversial, as inconsistent results are unable to confirm the ability of these cells to correctly integrate into the hostneural circuitry.

An alternative approach is utilizing the ability of hMSCs to secrete protective neurotrophic factors, growth factors and cytokines that exhibit immunomodulatory effects [63-65]. We look forward to having the first results obtained in the clinical trials are currently underway.

Human Pluripotent stem cells (hESCs, hpESCs, hiPSCs) have the ability to undergo unlimited proliferation and can differentiate into any specialized cell of the body. There are currently very efficient protocols for the generation of DAn from pluripotent stem cells. These DAn present molecular and functional properties very similar to those of VM DAn. However, the possibility of tumor formation, histocompatibility problems or ethical concerns are some of the challenges that lead to strict regulation of pluripotent stem cell therapy in most countries.

Human pluripotent stem cells possess the worrying potential of teratoma generation in the transplant area due to undifferentiated stem cell populations remaining in the grafts. Some possible strategies to reduce the risk of tumor formation after transplantation could be further improving the differentiation protocols to DAn (in order to obtain cultures phenotypically more homogeneous), to select efficiently the correct type of cells to be grafted or remove undifferentiated cells by using for example suicide genes. It will be also essential improve the isolation and differentiation of human pluripotent stem cells in GMP conditions, it means using animal products (feeder cells or sera) in order to obtain clinically applicable DAn. One of the great advantages of hiPSCs over hESCs is the ability to generate patient-specific cells, which would avoid the use of immunosuppressant. Unfortunately for the moment, the process seems to be too expensive. Several cell lines have to be generated for each patient, and these cell lines have to be characterized and properly analyzed, with particular attention to biosafety. It is estimated that the approximate cost of treating one single patient with autologous cells could be around one million dollars $[86,87]$. A possible solution proposed by Yamanaka is the creation of human stem cell banks for therapeutic use, where a standard matrix of different cell lines containing the main HLA types, are available and can be tolerated by $80 \%$ of the population. Thus it is intended to reduce the deriving and testing time in each patient, alleviate histocompatibility problems and reduce therapy costs [88] (Table 2). Another important problem to be solved in hiPS cells is the observation of mutations in some of the cell lines, which were not present in the original patient fibroblasts; probably due to the reprogramming process itself [89]. Thereby improving the reprogramming process is essential for the future therapeutic application of these cells.

\section{Acknowledgements}

The authors wish to thank members of their laboratory for their research work and fruitful discussions. Research at the authors' laboratory was funded by the MICINN-ISCIII (PI-10/00291 and MPY1412/09), MINECO (SAF2015-71140-R) and Comunidad de Madrid (NEUROSTEMCM consortium; S2010/BMD-2336).

\section{Author disclosure statement}

The authors declare that they have no competing interests.

\section{References}

1. Buttery PC, Barker RA (2014) Treating Parkinson's disease in the 21st century: can stem cell transplantation compete? J Comp Neurol 522: 2802-2816. [Crossref]

2. Martínez-Morales PL, Liste I (2012) Stem cells as in vitro model of Parkinson's disease. Stem Cells Int 2012: 980941. [Crossref]

3. Lindvall O, Kokaia Z (2009) Prospects of stem cell therapy for replacing dopamine neurons in Parkinson's disease. Trends Pharmacol Sci 30: 260-267. [Crossref]

4. Lindvall O, Kokaia Z (2009) Prospects of stem cell therapy for replacing dopamine neurons in Parkinson's disease. Trends Pharmacol Sci 30: 260-267. [Crossref]

5. Wang Q, Liu Y, Zhou J (2015) Neuroinflammation in Parkinson's disease and it potential as therapeutic target. Transl Neurodegener 4: 19. [Crossref]

6. More SV, Kumar H, Kim IS, Song SY, Choi DK (2013) Cellular and molecular mediators of neuroinflammation in the pathogenesis of Parkinson's disease. Mediators Inflamm 2013: 952375. [Crossref]

7. McGeer PL, McGeer EG (2008) Glial reactions in Parkinson's disease. Mov Disord 23: 474-483. [Crossref]

8. Savitt JM, Dawson VL, Dawson TM (2006) Diagnosis and treatment of Parkinson disease: molecules to medicine. J Clin Invest 116: 1744-1754. [Crossref] 
9. Lindvall O (2016) Clinical translation of stem cell transplantation in Parkinson's disease. J Intern Med 279: 30-40. [Crossref]

10. Prashanth LK, Fox S, Meissner WG (2011) 1-Dopa-induced dyskinesia-clinical presentation, genetics, and treatment. Int Rev Neurobiol 98: 31-54. [Crossref]

11. Poewe W (2009) Treatments for Parkinson disease--past achievements and current clinical needs. Neurology 72: S65-73. [Crossref]

12. Politis M, Wu K, Loane C (2014) Serotonergic mechanisms responsible for levodopainduced dyskinesias in Parkinson's disease patients. J Clin Invest 124 :1340-1349

13. Brundin P, Strecker RE, Clarke DJ, Widner H, Nilsson OG, et al. (1988) Can human fetal dopamine neuron grafts provide a therapy for Parkinson's disease? Prog Brain Res 78: 441-448. [Crossref]

14. Freed CR, Greene PE, Breeze RE, Tsai WY, DuMouchel W, et al. (2001) Transplantation of embryonic dopamine neurons for severe Parkinson's disease. N Engl J Med 344: 710-719. [Crossref]

15. Olanow CW, Goetz CG, Kordower JH, Stoessl AJ, Sossi V, et al. (2003) A doubleblind controlled trial of bilateral fetal nigral transplantation in Parkinson's disease. Ann Neurol 54: 403-414. [Crossref]

16. Isacson O, Bjorklund LM, Schumacher JM (2003) Toward full restoration of synaptic and terminal function of the dopaminergic system in Parkinson's disease by stem cells. Ann Neurol 53 Suppl 3: S135-146. [Crossref]

17. Ganz J, Lev N, Melamed E, Offen D (2011) Cell replacement therapy for Parkinson's disease: how close are we to the clinic? Expert Rev Neurother 11: 1325-1339. [Crossref]

18. Rath A, Klein A, Papazoglou A (2013) Survival and functional restoration of human fetal ventral mesencephalon following transplantation in a rat model of Parkinson's disease. Cell Transplant 22: 1281-1293

19. Piquet AL, Venkiteswaran K, Marupudi NI, Berk M, Subramanian T (2012) The immunological challenges of cell transplantation for the treatment of Parkinson's disease. Brain Res Bull 88: 320-331. [Crossref]

20. Arenas E (2010) Towards stem cell replacement therapies for Parkinson's disease Biochem Biophys Res Commun 396: 152-156. [Crossref]

21. Piccini P, Pavese N, Hagell P, Reimer J, Björklund A, et al. (2005) Factors affecting the clinical outcome after neural transplantation in Parkinson's disease. Brain 128: 2977 2986. [Crossref]

22. Abbott A (2014) Fetal-cell revival for Parkinson's. Nature 510: 195-196. [Crossref]

23. Moore SF, Guzman NV, Mason SL, Williams-Gray CH, Barker RA (2014) Which patients with Parkinson's disease participate in clinical trials? One centre's experiences with a new cell based therapy trial (TRANSEURO). J Parkinsons Dis 4: 671-676. [Crossref]

24. González C, Bonilla S, Flores A, Cano E, Liste I (2016) An Update on Human Stem Cell-Based Therapy in Parkinson's Disease. Curr Stem Cell Res Ther 11: 561-568. [Crossref]

25. Li W, Englund E, Widner H (2016) Extensive graft-derived dopaminergic innervation is maintained 24 years after transplantation in the degenerating parkinsonian brain. Proc Natl Acad Sci USA 113: 6544-6549

26. Kriks S, Shim JW, Piao J, Ganat YM, Wakeman DR, et al. (2011) Dopamine neurons derived from human ES cells efficiently engraft in animal models of Parkinson's disease. Nature 480: 547-551. [Crossref]

27. Cho MS, Hwang DY, Kim DW (2008) Efficient derivation of functional dopaminergic neurons from human embryonic stem cells on a large scale. Nat Protoc 3: 1888-1894. [Crossref]

28. Chambers SM, Fasano CA, Papapetrou EP, Tomishima M, Sadelain M, et al. (2009) Highly efficient neural conversion of human ES and iPS cells by dual inhibition of SMAD signaling. Nat Biotechnol 27: 275-280. [Crossref]

29. Malmersjö S, Liste I, Dyachok O, Tengholm A, Arenas E, et al. (2010) Ca2+ and cAMP signaling in human embryonic stem cell-derived dopamine neurons. Stem Cells Dev 19: 1355-1364. [Crossref]

30. Soldner F, Hockemeyer D, Beard C, Gao Q, Bell GW, et al. (2009) Parkinson's disease patient-derived induced pluripotent stem cells free of viral reprogramming factors. Cell 136: 964-977. [Crossref]

31. Hargus G, Cooper O, Deleidi M (2010) Differentiated Parkinson patient-derived induced pluripotent stem cells grow in the adult rodent brain and reduce motor asymmetry in Parkinsonian rats. Proc Natl Acad Sci 107: 15921-15926
32. Nguyen HN, Byers B, Cord B, Shcheglovitov A, Byrne J, et al. (2011) LRRK2 mutant iPSC-derived DA neurons demonstrate increased susceptibility to oxidative stress. Cell Stem Cell 8: 267-280. [Crossref]

33. Sánchez-Danés A, Richaud-Patin Y, Carballo-Carbajal I, Jiménez-Delgado S, Caig $\mathrm{C}$, et al. (2012) Disease-specific phenotypes in dopamine neurons from human iPSbased models of genetic and sporadic Parkinson's disease. EMBO Mol Med 4: 380-395. [Crossref]

34. Courtois ET, Castillo CG, Seiz EG, Ramos M, Bueno C, et al. (2010) In vitro and in vivo enhanced generation of human $\mathrm{A} 9$ dopamine neurons from neural stem cells by Bcl-XL. J Biol Chem 285: 9881-9897. [Crossref]

35. Villa A, Liste I, Courtois ET, Seiz EG, Ramos M, et al. (2009) Generation and properties of a new human ventral mesencephalic neural stem cell line. Exp Cell Res 315: 1860-1874. [Crossref]

36. Lévesque MF, Neuman T, Rezak M (2009) Therapeutic microinjection of autologous adult human neural stem cells and differentiated neurons for Parkinson's disease: fiveyear post-operative outcome. The Open Stem Cell Journal 1: 20-29

37. Glavaski-Joksimovic A1, Bohn MC (2013) Mesenchymal stem cells and neuroregeneration in Parkinson's disease. Exp Neurol 247: 25-38. [Crossref]

38. Bongso A, Fong CY, Gauthaman K (2008) Taking stem cells to the clinic: Major challenges. J Cell Biochem 105: 1352-1360. [Crossref]

39. Zhang D, Kilian KA (2013) The effect of mesenchymal stem cell shape on the maintenance of multipotency. Biomaterials 34: 3962-3969. [Crossref]

40. Macias MI, Grande J, Moreno A, Domínguez I, Bornstein R, et al. (2010) Isolation and characterization of true mesenchymal stem cells derived from human term decidua capable of multilineage differentiation into all 3 embryonic layers. Am J Obstet Gynecol 203: 495. [Crossref]

41. Lindvall O, Barker RA, Brüstle O, Isacson O, Svendsen CN (2012) Clinical translation of stem cells in neurodegenerative disorders. Cell Stem Cell 10: 151-155. [Crossref]

42. Martínez-Serrano A, Liste I (2010) Recent progress and challenges for the use of stem cell derivatives in neuron replacement therapy of Parkinson's disease. Future Neurology 5: 161-165

43. Ramos-Moreno T, Lendínez JG, Pino-Barrio MJ, Del Arco A, Martínez-Serrano A (2012) Clonal human fetal ventral mesencephalic dopaminergic neuron precursors for cell therapy research. PLoS One 7: e52714. [Crossref]

44. Kim HJ, McMillan E, Han F et al. (2009) Regionally specified human neural progenitor cells derived from the mesencephalon and forebrain undergo increased neurogenesi following overexpression of ASCL1. Stem Cells 27: 390-398

45. Bonnamain V, Neveu I, Naveilhan P (2012) Neural stem/progenitor cells as a promising candidate for regenerative therapy of the central nervous system. Front Cell Neurosci 6: 17. [Crossref]

46. Kallur T, Darsalia V, Lindvall O (2006) Human fetal cortical and striatal neural stem cells generate region-specific neurons in vitro and differentiate extensively to neurons after intrastriatal transplantation in neonatal rats. J Neurosci Res 84: 1630-1644

47. Cacci E, Villa A, Parmar M, Cavallaro M, Mandahl N, et al. (2007) Generation of human cortical neurons from a new immortal fetal neural stem cell line. Exp Cell Res 313: 588-601. [Crossref]

48. Ribeiro D, Laguna Goya R, Ravindran G, Vuono R, Parish CL, et al. (2013) Efficient expansion and dopaminergic differentiation of human fetal ventral midbrain neural stem cells by midbrain morphogens. Neurobiol Dis 49: 118-127. [Crossref]

49. Collins E, Gu F, Qi M, Molano I, Ruiz P, et al. (2014) Differential efficacy of human mesenchymal stem cells based on source of origin. J Immunol 193: 4381-4390. [Crossref]

50. Zuk PA, Zhu M, Ashjian P, De Ugarte DA, Huang JI, et al. (2002) Human adipose tissue is a source of multipotent stem cells. Mol Biol Cell 13: 4279-4295. [Crossref]

51. Erices A, Conget P, Minguell JJ (2000) Mesenchymal progenitor cells in human umbilical cord blood. Br J Haematol 109: 235-242. [Crossref]

52. Gronthos S, Mankani M, Brahim J, Robey PG, Shi S (2000) Postnatal human dental pulp stem cells (DPSCs) in vitro and in vivo. Proc Natl Acad Sci U S A 97: 1362513630. [Crossref]

53. Abumaree MH, Jumah MA, Kalionis B (2013) Human placental mesenchymal stem cells (pMSCs) play a role as immune suppressive cells by shifting macrophage differentiation from inflammatory M1 to anti-inflammatory M2 macrophages. Stem Cell Rev 9: 620-641 
54. Paul G, Özen I, Christophersen NS, Reinbothe T, Bengzon J, et al. (2012) The adult human brain harbors multipotent perivascular mesenchymal stem cells. PLoS One 7 : e35577. [Crossref]

55. Teixeira FG, Carvalho MM, Sousa N, Salgado AJ (2013) Mesenchymal stem cells secretome: a new paradigm for central nervous system regeneration? Cell Mol Life Sci 70: 3871-3882. [Crossref]

56. Lunn JS, Sakowski SA, Hur J, Feldman EL (2011) Stem cell technology for neurodegenerative diseases. Ann Neurol 70: 353-361. [Crossref]

57. Trounson A, Pera M (2001) Human embryonic stem cells. Fertil Steril 76: 660-661. [Crossref]

58. Joyce N, Annett G, Wirthlin L, Olson S, Bauer G, et al. (2010) Mesenchymal stem cells for the treatment of neurodegenerative disease. Regen Med 5: 933-946. [Crossref]

59. Satija NK, Singh VK, Verma YK, Gupta P, Sharma S, et al. (2009) Mesenchymal stem cell-based therapy: a new paradigm in regenerative medicine. J Cell Mol Med 13: 43854402. [Crossref]

60. Hayashi T, Wakao S, Kitada M, Ose T, Watabe H, et al. (2013) Autologous mesenchymal stem cell-derived dopaminergic neurons function in parkinsonian macaques. $J$ Clin Invest 123: 272-284. [Crossref]

61. Kumar A, Dudal S, Sundari AT et al. (2016) Dopaminergic-primed fetal liver mesenchymal stromal-like cells can reverse parkinsonian symptoms in 6 hydroxydopamine-lesioned mice. Cytotherapy 18: 307-319

62. Chun SY, Soker S, Jang YJ, Kwon TG, Yoo ES (2016) Differentiation of Human Dental Pulp Stem Cells into Dopaminergic Neuron-like Cells in Vitro. J Korean Med Sci 31: 171-177. [Crossref]

63. Hardy SA, Maltman DJ, Przyborski SA (2008) Mesenchymal stem cells as mediators of neural differentiation. Curr Stem Cell Res Ther 3: 43-52. [Crossref]

64. Kim YJ, Park HJ, Lee G, Bang OY, Ahn YH, et al. (2009) Neuroprotective effects of human mesenchymal stem cells on dopaminergic neurons through anti-inflammatory action. Glia 57: 13-23. [Crossref]

65. Ng TK, Fortino VR, Pelaez D, Cheung HS (2014) Progress of mesenchymal stem cell therapy for neural and retinal diseases. World J Stem Cells 6: 111-119. [Crossref]

66. Nagatsu T, Mogi M, Ichinose H, Togari A (2000) Cytokines in Parkinson's disease. $J$ Neural Transm Suppl: 143-151. [Crossref]

67. Hoch AI, Binder BY, Genetos DC, Leach JK (2012) Differentiation-dependent secretion of proangiogenic factors by mesenchymal stem cells. PLoS One 7: e35579. [Crossref]

68. Siniscalco D, Giordano C, Galderisi U, Luongo L, Alessio N, et al. (2010) Intra-brain microinjection of human mesenchymal stem cells decreases allodynia in neuropathic mice. Cell Mol Life Sci 67: 655-669. [Crossref]

69. Chamberlain G, Fox J, Ashton B (2007) Concise review: mesenchymal stem cells: their phenotype, differentiation capacity, immunological features, and potential for homing. Stem Cells 25: 2739-2749

70. Kitada M, Dezawa M (2012) Parkinson's disease and mesenchymal stem cells: potential for cell-based therapy. Parkinsons Dis 2012: 873706. [Crossref]

71. Schwarz J, Storch A (2010) Transplantation in Parkinson's disease: will mesenchymal stem cells help to reenter the clinical arena? Transl Res 155: 55-56. [Crossref]
72. Thomson JA, Itskovitz-Eldor J, Shapiro SS (1998) Embryonic stem cell lines derived from human blastocysts. Science 282: 1145-1147

73. Grealish S, Diguet E, Kirkeby A, Mattsson B, Heuer A, et al. (2014) Human ESC derived dopamine neurons show similar preclinical efficacy and potency to fetal neurons when grafted in a rat model of Parkinson's disease. Cell Stem Cell 15: 653665. [Crossref]

74. Kirkeby A, Grealish S, Wolf DA (2012) Generation of regionally specified neural progenitors and functional neurons from human embryonic stem cells under defined conditions. Cell Rep 1: 703-714

75. Kirkeby A, Nelander J, Parmar M (2013) Generating regionalized neuronal cells from pluripotency, a step-by-step protocol. Front Cell Neurosci 6: 64. [Crossref]

76. Petit GH1, Olsson TT, Brundin P (2014) The future of cell therapies and brain repair: Parkinson's disease leads the way. Neuropathol Appl Neurobiol 40: 60-70. [Crossref]

77. Martínez-Morales PL, Revilla A, Ocaña I, González C, Sainz P, et al. (2013) Progress in stem cell therapy for major human neurological disorders. Stem Cell Rev 9: 685-699. [Crossref]

78. Tabar VS (2016) 133 The Development of Human Embryonic Stem Cell-Derived Dopamine Neurons for Clinical Use in Parkinson Disease. Neurosurgery 63 Suppl 1: 154-155. [Crossref]

79. Barker RA, Parmar M, Kirkeby A, Björklund A (2016) Are Stem Cell-Based Therapie for Parkinson's Disease Ready for the Clinic in 2016? J Parkinsons Dis 6: 57-63. [Crossref]

80. Revazova ES, Turovets NA, Kochetkova OD (2007) Patient-specific stem cell lines derived from human parthenogenetic blastocysts. Cloning and Stem Cells 9: 432-449

81. Phanstiel DH, Brumbaugh J, Wenger CD, Tian S, Probasco MD, et al. (2011) Proteomic and phosphoproteomic comparison of human ES and iPS cells. Nat Methods 8: 821827. [Crossref]

82. Takahashi K, Yamanaka S (2006) Induction of pluripotent stem cells from mouse embryonic and adult fibroblast cultures by defined factors. Cell 126: 663-676. [Crossref]

83. Revilla A, González C, Iriondo A, Fernández B, Prieto C, et al. (2015) Current advances in the generation of human iPS cells: implications in cell-based regenerative medicine. J Tissue Eng Regen Med. [Crossref]

84. Pasi CE, Dereli-Öz A, Negrini S, Friedli M, Fragola G, et al. (2011) Genomic instability in induced stem cells. Cell Death Differ 18: 745-753. [Crossref]

85. Lister R, Pelizzola M, Kida YS, Hawkins RD, Nery JR, et al. (2011) Hotspots of aberrant epigenomic reprogramming in human induced pluripotent stem cells. Nature 471: 68-73. [Crossref]

86. Ben-David U, Benvenisty N (2011) The tumorigenicity of human embryonic and induced pluripotent stem cells. Nat Rev Cancer 11: 268-277. [Crossref]

87. Blair NF, Barker RA (2016) Making it personal: the prospects for autologous pluripoten stem cell-derived therapies. Regen Med 11: 423-425. [Crossref]

88. Rosemann A (2015) Stem cell treatments for neurodegenerative diseases: challenges from a science, business and healthcare perspective. Neurodegener Dis Manag 5: 85-87

89. Cyranoski D (2012) Stem-cell pioneer banks on future therapies. Nature 488: 139 [Crossref]

Copyright: (C2016 Palmer C. This is an open-access article distributed under the terms of the Creative Commons Attribution License, which permits unrestricted use, distribution, and reproduction in any medium, provided the original author and source are credited. 